\title{
The block rotation in the Uetsu area, Northern Part of Niigata Prefecture, Japan
}

\author{
Koichiro Mino ${ }^{1 *}$, Atsushi Yamaji ${ }^{1}$, and Naoto Ishikawa ${ }^{2}$ \\ ${ }^{1}$ Division of Earth and Planetary Sciences, Graduate School of Science, Kyoto University, Kyoto 606-8502, Japan \\ ${ }^{2}$ School of Earth Sciences, IHS, Kyoto University, Kyoto 606-8501, Japan
}

(Received April 12, 2000; Revised January 24, 2001; Accepted February 22, 2001)

\begin{abstract}
Paleomagnetic and geologic studies were made in the Uetsu area, NE Japan, to clarify the Miocene intra-arc deformation associated with the Japan Sea opening. We obtained paleomagnetic directions from the Early to Middle Miocene pyroclastic rocks and lavas in the area. The average paleomagnetic direction is $D=28.0^{\circ}, I=48.7^{\circ}$ and $\alpha_{95}=9.6^{\circ}$. It suggests that the clockwise rotation occurred in this area, which is opposite to the counter-clockwise rotation of NE Japan. A fault was discovered which could be the boundary of this rotating domain. The dextral movement is recognized for this fault, concordant with the clockwise rotation in the area. These paleomagnetic and structural data suggest that the clockwise block rotations occurred in the Uetsu area, accompanied by the dextral deformation.
\end{abstract}

\section{Introduction}

Paleomagnetic studies have shown that NE Japan consisted primarily of counter-clockwise (CCW) rotating blocks when the Japan Sea opened (Sasajima, 1981; Otofuji et al., 1985, 1994; Hoshi and Matsubara, 1998; Yamaji et al., 1999). However, clockwise (CW) deflections are reported from the Takadate, Yanagawa, Matsushima areas, indicating CW rotations (Oda et al., 1989; Yamazaki, 1989). This fact suggests complex intra-arc deformations in NE Japan. They are still matters of debate what kind of geologic structures accommodated those block rotations and that there were blocks with opposite sense of rotation.

The Uetsu area, southwestern NE Japan, is one of the areas where easterly deflected data have been obtained (Fig. 1). They are ascribed to $\mathrm{CW}$ block rotations accompanied by strike-slip faultings between CCW rotating blocks (Otofuji et al., 1985; Yamaji et al., 1999). However, their paleomagnetic data are obtained mostly from a single geologic unit that covers a short period of time. Therefore, it is not clear whether they are really tectonic in origin. The purpose of this paper is to present new paleomagnetic data to demonstrate the tectonic origin of easterly deflected paleomagnetic directions and to describe a fault zone that was found in this study and is likely to be related to the block rotations.

\section{Geologic Setting and Sampling}

\subsection{Geology of the study area}

In the Uetsu area, there are Early Miocene grabens that are filled with lacustrine and pyroclastic deposits (Takahama, 1976; Agency of Natural Resources and Energy, 1982; Yamaji, 1989; Hataya and Otsuki, 1991). The

\footnotetext{
* Now at Fuji Xerox Co., Ltd.
}

graben-fills are covered by Middle Miocene transgressive marine sequence. The basement of the graben-fills consists mainly of Mesozoic accretionary complexes, CretaceousPaleogene plutonic rocks and the Early Miocene ignimbrites called the Kitaoguni Formation. The stratigraphy of the area is shown in Fig. 2.

The basement of the Miocene deposits consists of plutonic and mylonitic rocks (Yamaji, 1989). A NW-SE trending mylonite zone called the Nihonkoku Mylonite transverses the northern Uetsu area. The mylonite is intruded by granite at its northern border, but grades into the Iwafune Granite to the south of the mylonite (Takahashi, 1998). The mylonitization was Cretaceous in age and microstructures indicate sinistral transtension (Takahashi, 1998). The $\mathrm{K}$-Ar ages ranging from 90 to $50 \mathrm{Ma}$ are reported from the Iwafune Granite (Agency of Natural Resources and Energy, 1982).

The Miocene deposits rest on the basement with unconformity, which consist of the Kitaoguni, Tenjosan, Asahi, Wasada Formations and the Osudo Shale (Agency of Natural Resources and Energy, 1982). The Kitaoguni Formation is extensive rhyolitic ignimbrites which occupy the basal horizon of Miocene sequence, which is composed of rhyolitic lavas and tuffs in the study area. This formation is dated at $22.4 \pm 0.6 \mathrm{Ma}$ by fission-track method (Ganzawa, 1987). The K-Ar age at $22 \mathrm{Ma}$ is also reported by Ueda et al. (1973). It yields a K-Ar age at $20.2 \pm 1.0 \mathrm{Ma}$ in the Tamaniwa area to the southeast of the Uetsu area (Yanagisawa and Yamamoto, 1998). The Tenjosan Formation lies on the Kitaoguni Formation and is composed of altered andesitic lavas and tuffs. This formation is correlated to the Oizumi Formation in the northern Uetsu area that yields K-Ar ages at $19.5 \pm 1.0$ and $19.9 \pm 1.0 \mathrm{Ma}$ (Agency of Natural Resources and Energy, 1982). The Asahi Formation and Osudo Shale consist mainly of marine mudstones. The Asahi Formation yields planktonic foraminiferas which 


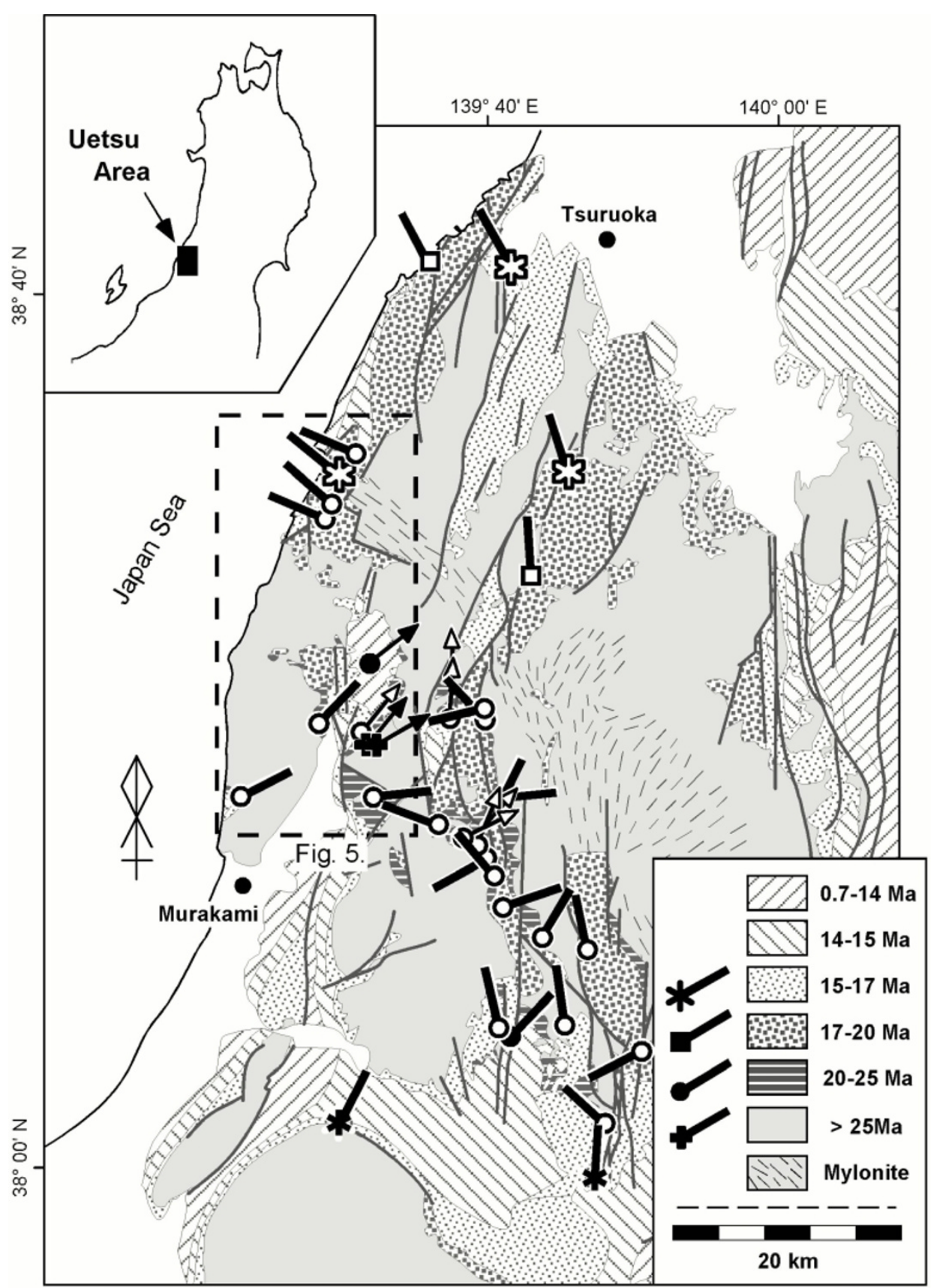

Fig. 1. Geological map of the Uetsu area with paleomagnetic directions reported by preceding studies. Bars and arrows with symbols indicate the paleomagnetic directions obtained by Yamaji et al. (1999) and Otofuji et al. (1985), respectively. Symbols mean their ages, and solid and open ones indicate paleomagnetic data from normal- and reversed-polarity sites. Those from reversed-polarity sites are inverted by $180^{\circ}$. Geologic map after Yamaji et al. (1999).

is correlated to Blow's (1969) N.9 zone (Agency of Natural Resources and Energy, 1982). The Wasada Formation is mainly composed of basaltic to andesitic lavas in the study area.

The Myojin-iwa Andesite is of the Pliocene in age, and unconformably overlies these Miocene strata. This unit consists of andesitic lavas and conglomerates. The K-Ar age at $3.1 \pm 0.2 \mathrm{Ma}$ is reported from this formation (Agency of Natural Resources and Energy, 1982).

\subsection{Paleomagnetic samples}

From these formations, we collected samples at 39 sites for paleomagnetic measurement: 11 sites in the Kitaoguni, eight in the Tenjosan, two in the Asahi, one in the Osudo Shale, one in the Wasada Formation, and 16 in the granite (Fig. 5). Three to six rock samples of hand size were collected at each site. The orientation of each sample was measured using a magnetic compass. The orientations of bedding planes were also measured for tilt correction. Eutaxitic textures in welded tuffs were used as the marker of bedding plane. As for lavas, we used bedding planes of overlying or underlying sediments. 


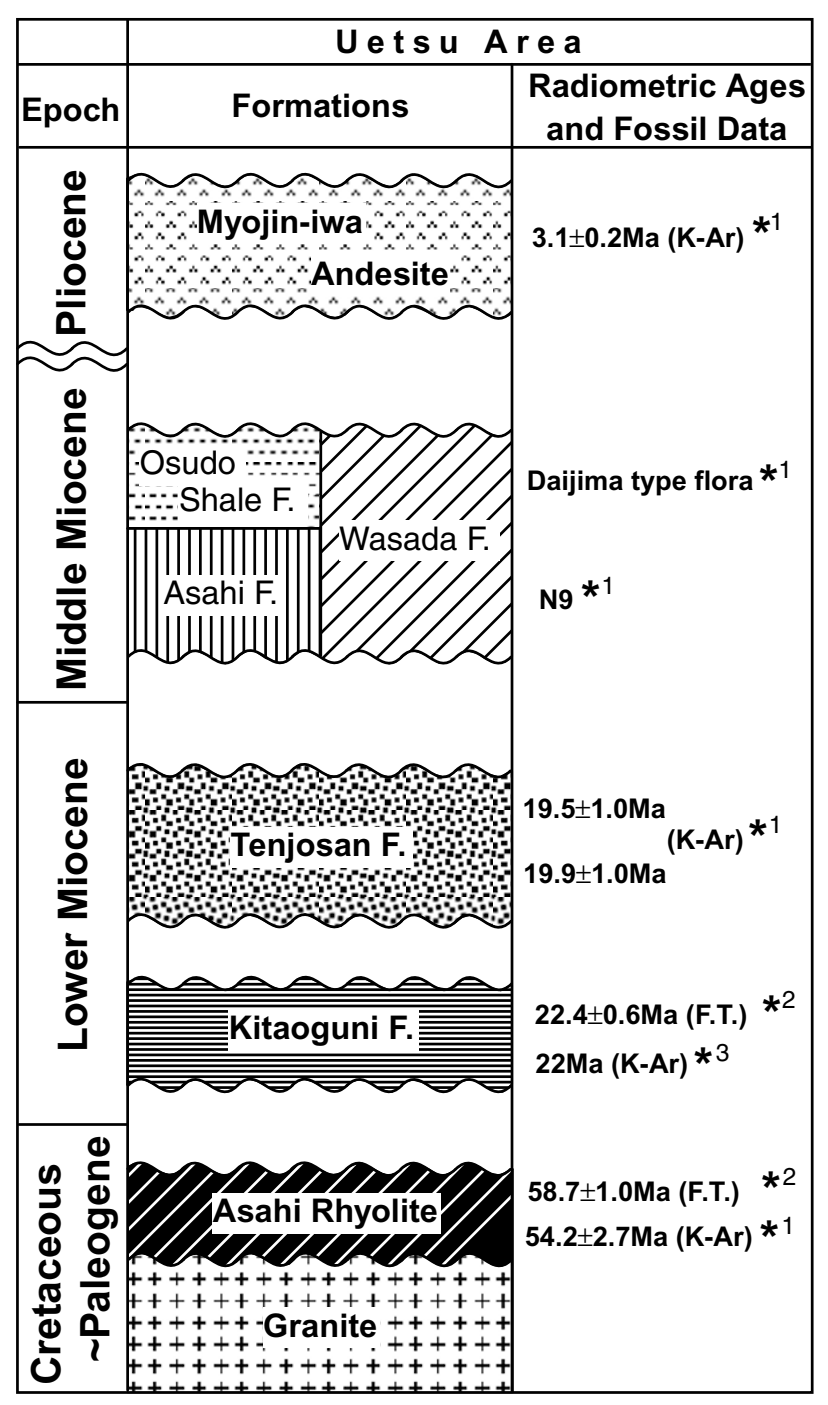

Fig. 2. Stratigraphy in the study area after the Agency of Natural Resources and Energy (1982) and Yamaji (1989). *1: Agency of Natural Resources and Energy (1982), *2: Ganzawa (1987), *3: Ueda et al. (1973).

\section{Paleomagnetic Measurements and Results}

Cylindrical specimens, $25 \mathrm{~mm}$ in diameter and $23 \mathrm{~mm}$ in length, were prepared in the laboratory from each rock sample. Natural remanent magnetizations (NRMs) of specimens were measured by a spinner magnetometer (Natsuhara Giken) or a cryogenic magnetometer (2G Enterprise) depending on their intensity. Stability of NRM was assessed by progressive thermal demagnetization (PThD). Measurement and PThD processes were carried out in a magnetically shielded room. The ambient magnetic field is lower than $1 \mu \mathrm{T}$ around the center of the room where measurements were performed. Samples were heated and cooled down in the furnace in which the residual field was lower than $5 \mathrm{nT}$. For each site, all specimens were heated from 100 to $500^{\circ} \mathrm{C}$ with intervals of $50^{\circ} \mathrm{C}$, and with $20^{\circ} \mathrm{C}$ intervals above $500^{\circ} \mathrm{C}$. Typical magnetic behaviors are shown in Fig. 3. They exhibited linear trends of vector endpoints decaying toward the origins of the vector endpoint diagrams (Zijderveld, 1967) at the demagnetization levels above $500^{\circ} \mathrm{C}$ (Fig. 3). This high-temperature (high-T) component was regarded as a characteristic remanent magnetization (ChRM) for each specimen. Its direction was determined based on Kirschvink's (1980) method, anchoring the best fit line on the origin of the diagram. A site-mean direction was determined from ChRMs for each site, and its relevance was tested by Fisher's (1953) statistics: if the radius of the $95 \%$ confidence circle is smaller than $20^{\circ}$, the average is supposed to be significant. These site-mean directions were tilt-corrected by the conventional method. The formationmean directions were calculated from them, and it was investigated whether tilt correction alters the degrees of concentration.

In the Kitaoguni Formation, stable magnetic behaviors were obtained from rhyolitic welded tuffs at eight sites out of 11 sites. They consist of one or two components (Fig. 3). The low-temperature (low-T) components were removed by heating up to $250^{\circ} \mathrm{C}$. They are parallel to the present geomagnetic field, suggesting viscous remanent magnetizations (VRMs) in origin due to the recent geomagnetic field. After the removal of low-T components, these specimens showed ChRMs around the temperature range between 500 and $600^{\circ} \mathrm{C}$. All of these high-T components were obtained from reversed-polarity sites. This supports the suggestion that the Early Miocene rhyolitic tuffs and lavas in the Uetsu area belong to a single pyroclastic flow sheet (Yanagisawa and Yamamoto, 1998). Samples from the other three sites exhibited complete removals of magnetization below $250^{\circ} \mathrm{C}$ or erratic behaviors during PThD, providing no stable NRM.

In the Tenjosan Formation, specimens of seven sites showed stable magnetic behaviors. They are of altered andesitic welded tuffs. NRMs from six sites exhibited two components, and those from one site (site 6) showed four components (Fig. 3). The components isolated below $250^{\circ} \mathrm{C}$ had similar directions to the present geomagnetic field. They may also be VRMs. Above $500^{\circ} \mathrm{C}, 30$ to $40 \%$ of the initial intensity still remained unremoved for each specimen, and this high-T component was cleared off at about $620^{\circ} \mathrm{C}$. All of them are from normal-polarity sites. Two kinds of middle-temperature components were obtained from the site 6. The lower-temperature (M1) component ranged between about 250 and $400^{\circ} \mathrm{C}$, and the higher-temperature (M2) component between about 400 and $500^{\circ} \mathrm{C}$ (Table 1). The M1 and M2 components were observed only at one site. Therefore, their origins are not discussed in this paper.

In the Wasada Formation, specimens from only one site showed stable magnetic behaviors, which consist of one stable component (Fig. 3). They are of basaltic to andesitic lavas. They were stable above $500^{\circ} \mathrm{C}$ and completely removed at $630^{\circ} \mathrm{C}$ (Fig. 3). The stable components exhibit abrupt drops in intensity between 560 and $630^{\circ} \mathrm{C}$.

Granite samples showed complete removal of magnetizations under the temperature level lower than $300^{\circ} \mathrm{C}$. It is not probable that they are characteristic, so they are not taken into consideration in the following discussion.

Site-mean directions with $\alpha_{95}$ smaller than $20^{\circ}$ were obtained from 12 sites: six from the Kitaoguni, five from the Tenjosan and one site from the Wasada Formation (Table 1). Figure 4 shows these site-mean directions before and after tilt correction. By tilt correction, the paleomagnetic data from the Kitaoguni and Tenjosan Formations were judged 

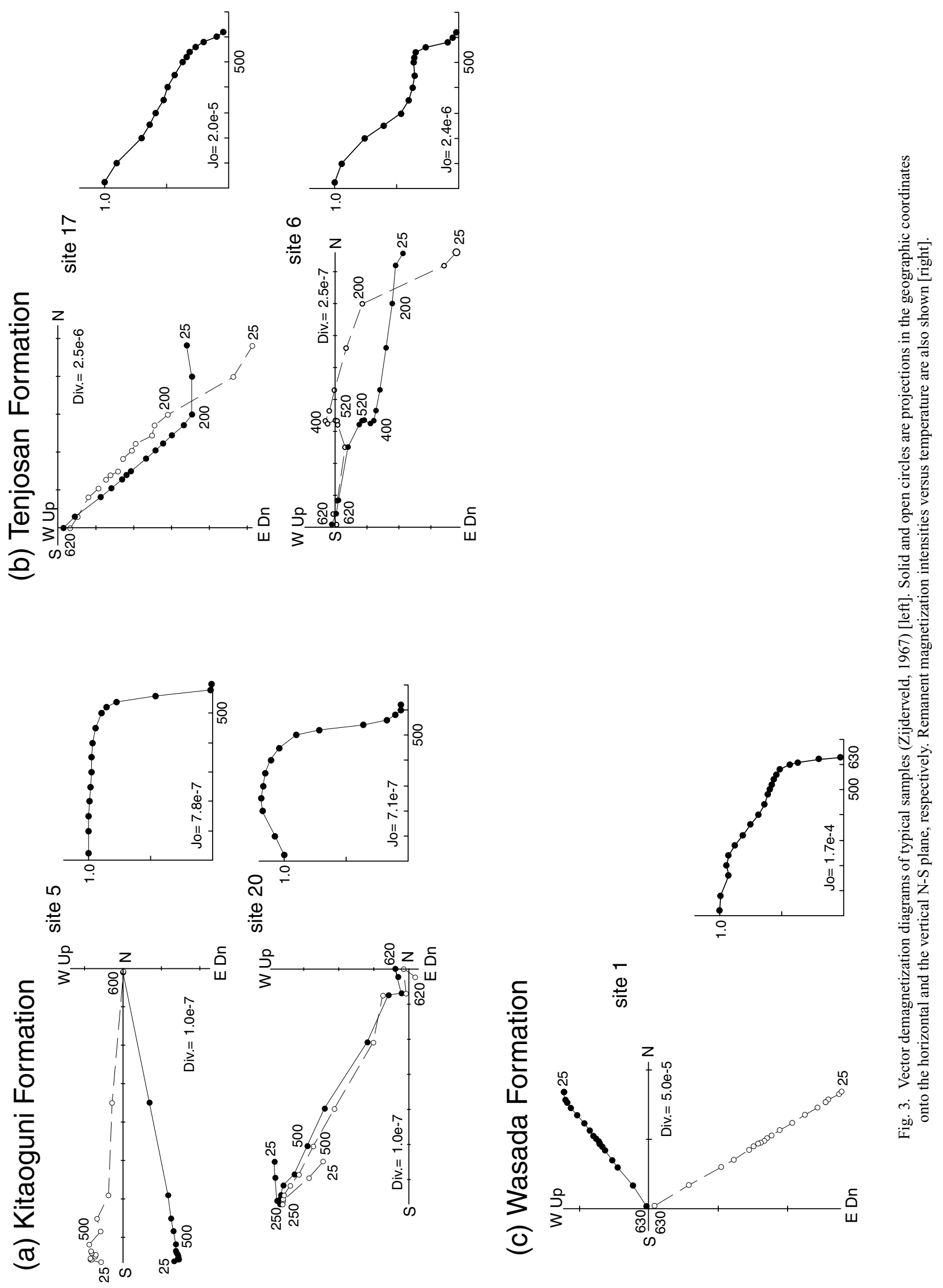


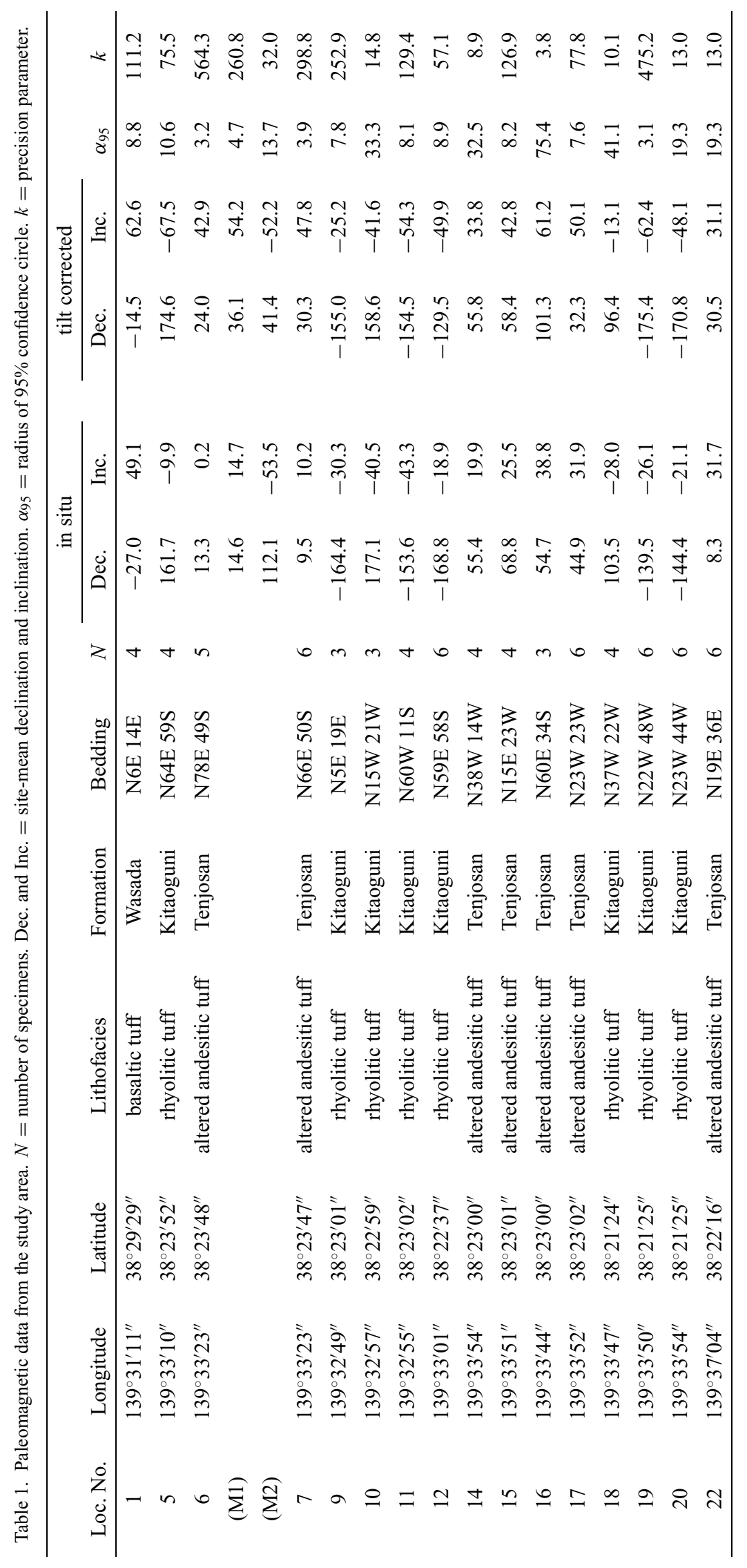



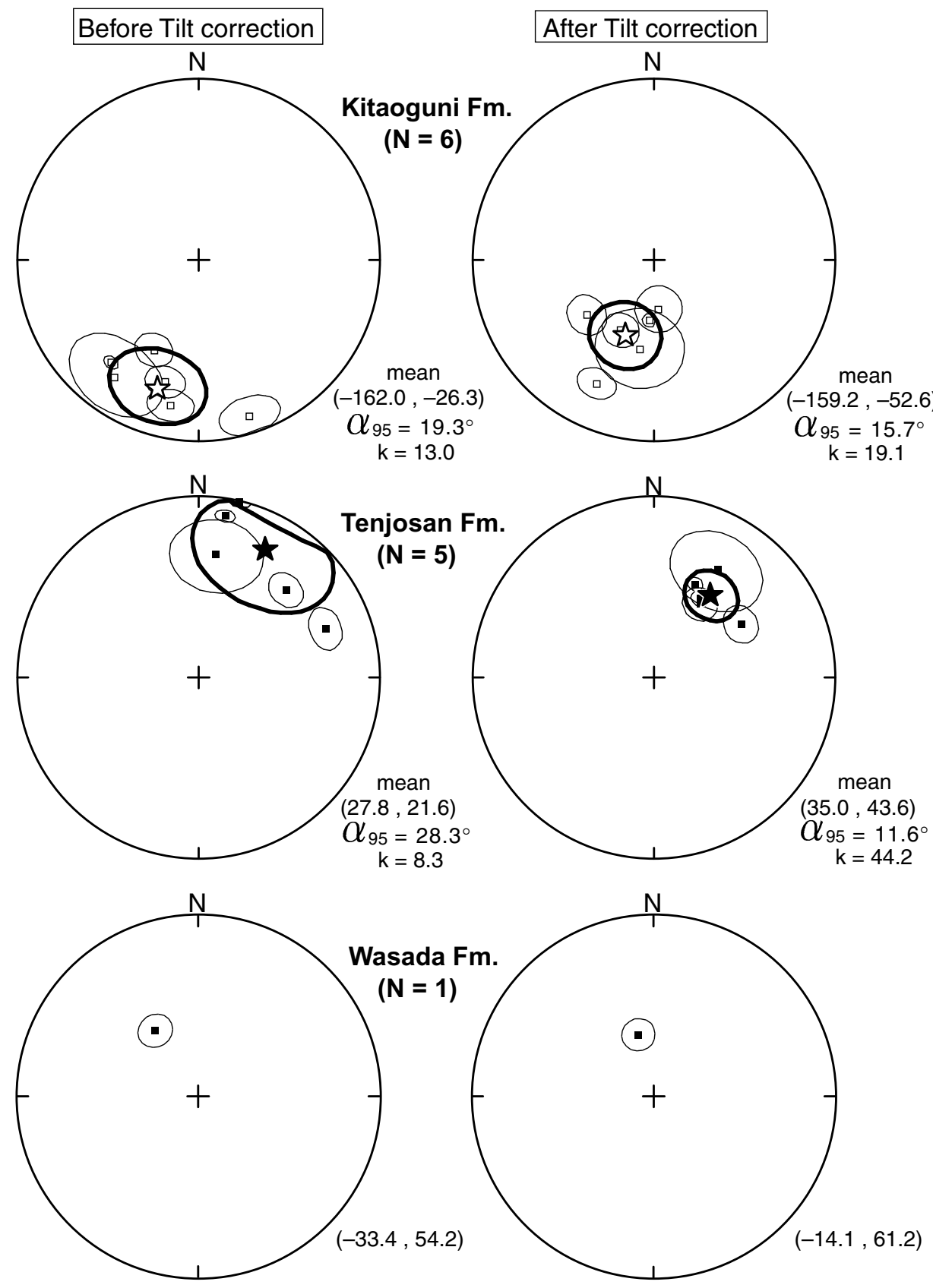

Fig. 4. Equal area projections of site-mean direction with $95 \%$ confidence circle for each formation. Solid symbols refer to the lower hemisphere, and open symbols to the upper hemisphere. Stars indicate the formation-mean directions before and after tilt correction.

to be improved. In the Kitaoguni Formation, the $\alpha_{95}$ decreases from $19.3^{\circ}$ to $15.7^{\circ}$, and the precision parameter $k$ increases from 13.0 to 19.1 by tilt correction (Fig. 4). In the Tenjosan Formation, the $\alpha_{95}$ of the formation-mean direction decreases from $28.3^{\circ}$ to $11.6^{\circ}$, and the $k$ increases from 8.3 to 44.2 . Thus, it is suggested that the Kitaoguni and Tenjosan Formations should have obtained ChRMs before tilting, indicating that they were of primary.

The Wasada Formation yielded the paleomagnetic data only at one site. Accordingly, we use the tilt-corrected data of this formation as the primary component hypothetically in the following sections.

\section{Discussion}

\subsection{Interpretation of paleomagnetic directions}

Site-mean paleomagnetic directions obtained in this study and those of previous researches are plotted on a geological map (Fig. 5). The spatial change in declination allows us to divide the area into two subareas; the northern subarea with westerly deflected magnetizations and the southern subarea with easterly deflected ones.

For the southern subarea, the representative direction was determined by averaging the site-mean directions (Fig. 6). The results are $D=28.0^{\circ}, I=48.7^{\circ}$ and $\alpha_{95}=9.6^{\circ}$. The tectonic rotation is the most likely explanation of these $\mathrm{CW}$ deflections for the following reasons: (1) the area-mean 


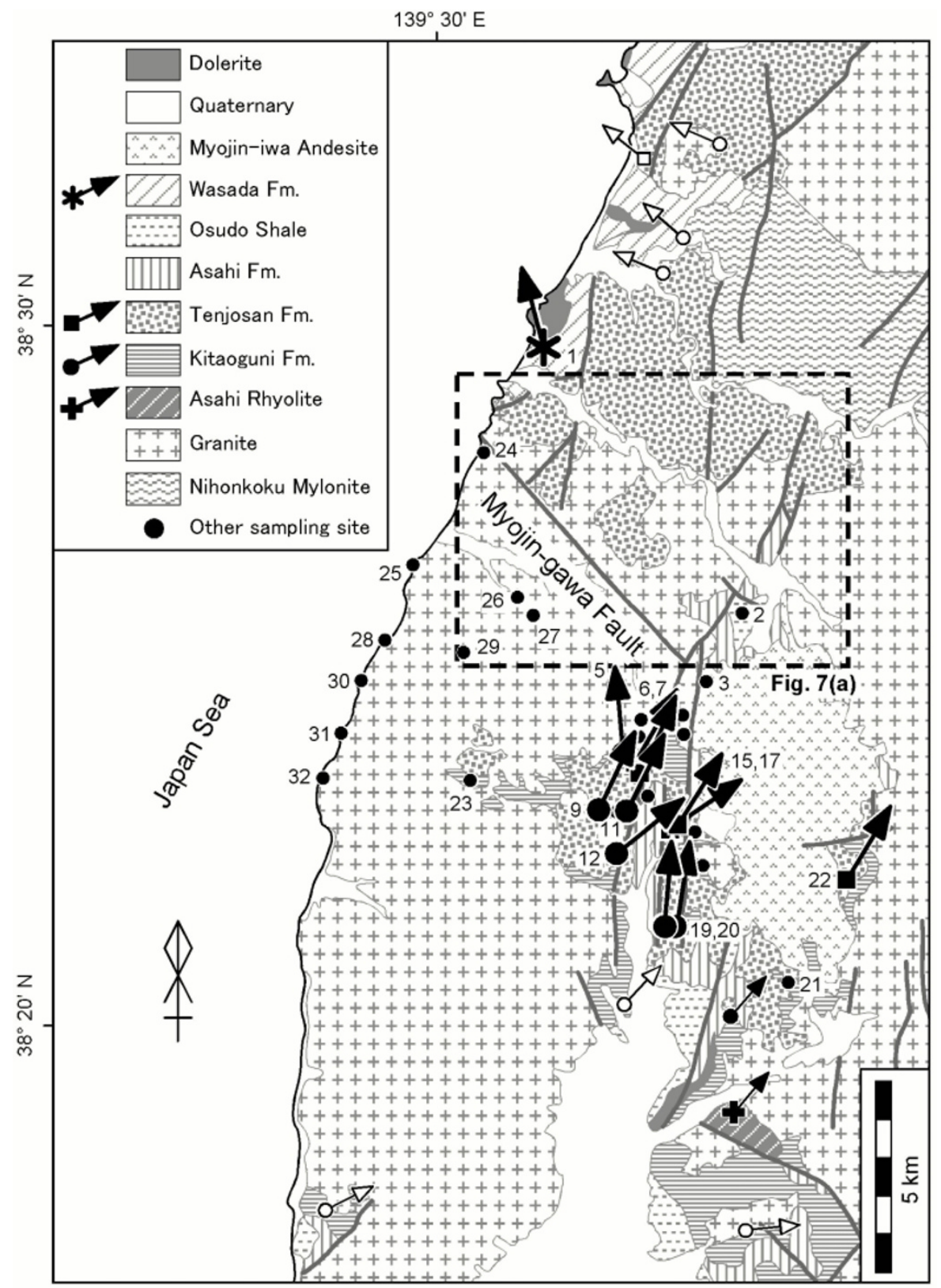

Fig. 5. Tilt-corrected paleomagnetic directions in the study area. Large arrows show declinations obtained in this study. Open and solid small arrows show data by Yamaji et al. (1999) and Otofuji et al. (1985), respectively. Solid circles show locations of sampling site with no reliable paleomagnetic data. The geological map is based on Agency of Natural Resources and Energy (1982).

direction is significantly deflected from the Miocene geographic north pole, which is not different so much from the present one (Fig. 6), (2) the direction averaging site-mean directions with normal-polarity is almost antipodal to the direction averaging those with reversed-polarity, (3) sampling horizons cover the time interval that is significantly longer than the time-scale of the secular variation (Fig. 2). These lines of evidence suggest the $\mathrm{CW}$ rotation in the southern subarea.

These NE-trending directions were obtained from the Kitaoguni and Tenjosan Formations. This suggests that the CW rotation was active after the deposition of the Tenjosan Formation. Therefore, the rotation is supposed to have occurred after 19-20 Ma (Fig. 2). Unfortunately, we cannot determine when this rotation had stopped because of the lack of paleomagnetic data from upper horizons than the Tenjosan Formation.

For the northern subarea, we have only one paleomagnetic direction, and it is impossible to analyze its significance statistically. However, the CCW rotation is supposed to have occurred in this area, based on the paleomagnetic data from the Atsumi area which also reports the NW-trending magnetizations (Yamaji et al., 1999).

\subsection{Differential rotation in the Uetsu area}

The northern and southern subarea rotated in the opposite sense to each other. What kind of geologic structures did accompany these rotations? The lack of paleomagnetic data around the boundary between two subareas make it impossi- 


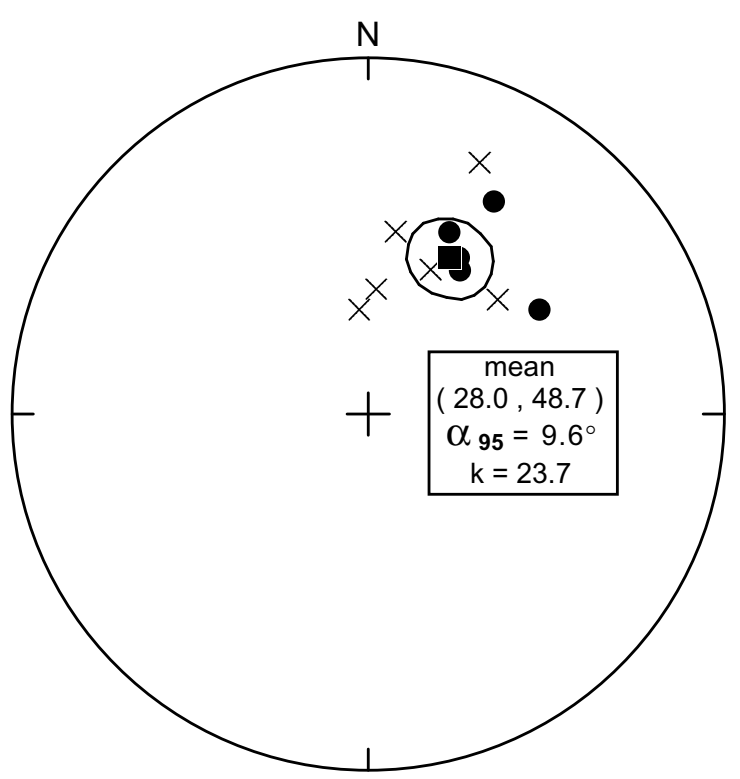

Fig. 6. Equal area projection of the direction averaging the paleomagnetic data obtained in the southern subarea (indicated by square) with $95 \%$ confidence circle (lower hemisphere), calculated by inverting site-mean directions from reversed-polarity sites by $180^{\circ}$. Circles show site-mean directions from normal-polarity sites, and crosses from reversed-polarity sites.

ble to describe the spatial change of rotation angles in detail (Fig. 5). However, the boundary does not coincide with the Nihonkoku-Miomote Mylonite Zone that is the northern extension of the Tanakura Shear Zone, one of major faults in NE Japan. It is not probable that this mylonite zone divides these two subareas.

In this study, a fault zone was discovered around the boundary, that seems to have accommodated some part of the differential rotation. It runs along the Myojin River from NW to SE, which is referred to as the Myojin-gawa Fault (Fig. 5). It is observed in the basement granite and not affect the Myojin-gawa Andesite of Pliocene. It crops out at localities A, B and C in Fig. 7(a). At the locality A, the fault zone is wider than $150 \mathrm{~m}$. It consists of granitic cataclasites and sheared rhyolitic dikes. Most shear planes strike NW-SE and dip at high angles. The pitch angles of striae on the planes are relatively shallow, indicating strikeslip movements (Fig. 7). Asymmetric microstructures in fault zones are useful to determine the sense of shear (Petit, 1987). Some small clasts have a thin ridge on the left hand side of them, making 'comet' patterns (Fig. 8(a)). A fault movement involves mechanical fragmentation, sliding and rotation of fragments; so-called cataclastic flow (Passchier and Trouw, 1996). These clasts disturbed cataclastic flow in the fault zone to form the asymmetric ridges and grooves (Fig. 8(b)), indicating the dextral shear of the Myojin-gawa Fault.

The trace of the Myojin-gawa Fault coincides with the line on which Yamaji et al. (1999) assume the boundary between the $\mathrm{CW}$ and $\mathrm{CCW}$ rotating domains. The dextral shear suggested by the microstructures is concordant with the CW rotation in the southern subarea. The dextral deformation is also suggested at a larger scale along the Nihonkoku-Miomote Tectonic Line from a left-step echelon array of Early Miocene grabens (Hataya and Otsuki, 1991). The 'domino model' relates a vertical-axis rotation with a strike-slip faulting, and states that the dextral deformation generally accompanies $\mathrm{CW}$ block rotations (Ron et al., 1984). These facts support the dextral motion of the Myojin-gawa Fault as the reason of the $\mathrm{CW}$ rotation in the southern subarea. However, it is difficult to explain the complexity of paleomagnetic data in the southern subarea by such a simple model (Fig. 1). It is argued that elliptical bodies embedded in homogeneously deforming matrix can rotate in both senses (Ghosh and Ramberg, 1976; Yamaji, 2000). In this case, the pure shear can bring rotations of blocks as well as the simple shear. Analogous mechanisms might bring these complex paleomagnetic directions in the study area. More detailed geologic and paleomagnetic data are necessary to relate geologic structures and paleomagnetic directions precisely.

What does this $\mathrm{CW}$ rotation mean in the tectonic history of the NE Japan? Hirooka et al. (1986) reported NWtrending magnetizations in the Sado and Fukushima areas which locates to the south of the Uetsu area. It indicates the Uetsu area belongs to the CCW-rotated NE Japan. Based on the paleomagnetic study, Yamaji et al. (1999) suggests the general CCW rotation of the NE Japan with local CW block rotations due to dextral transtension. However, all of their paleomagnetic data were obtained from reversedpolarity sites, and they possibly represented the geomagnetic fluctuations. Our data, which are from both normaland reversed-polarity sites, confirm the tectonic origin of those CW deflections and the kinematic model of Yamaji et al. (1999).

\section{Conclusion}

The paleomagnetic and geological study in the Uetsu area clarified the following points.

1. The paleomagnetic directions were obtained from the Kitaoguni and Tenjosan Formations of the Lower Miocene and the Wasada Formation of the Middle Miocene. The results combined with other studies divides the area into two subareas. The remanent magnetizations point NE in the southern subarea $\left(D=28.0^{\circ}, I=48.7^{\circ}\right.$ and $\left.\alpha_{95}=9.6^{\circ}\right)$. From the northern subarea, one site-mean direction which was westerly deflected was obtained. It is concordant with the paleomagnetic data of Yamaji et al. (1999).

2. The consistent paleomagnetic directions from both the Kitaoguni and Tenjosan Formations suggest that the NEtrending magnetizations in the southern subarea were resulted from $\mathrm{CW}$ rotations. It means that the $\mathrm{CW}$ rotation was active after the deposition of the Tenjosan Formation (19-20 Ma).

3. The NW-SE trending Myojin-gawa Fault was discovered around the boundary between the northern and southern subareas. Its location coincides with that of the domain boundary suggested by Yamaji et al. (1999). The dextral motion is suggested in this fault, which is consistent with the $\mathrm{CW}$ rotation in the southern subarea. It is probable that the movement of this fault bring $\mathrm{CW}$ block rotations in the southern subarea. 
(a)
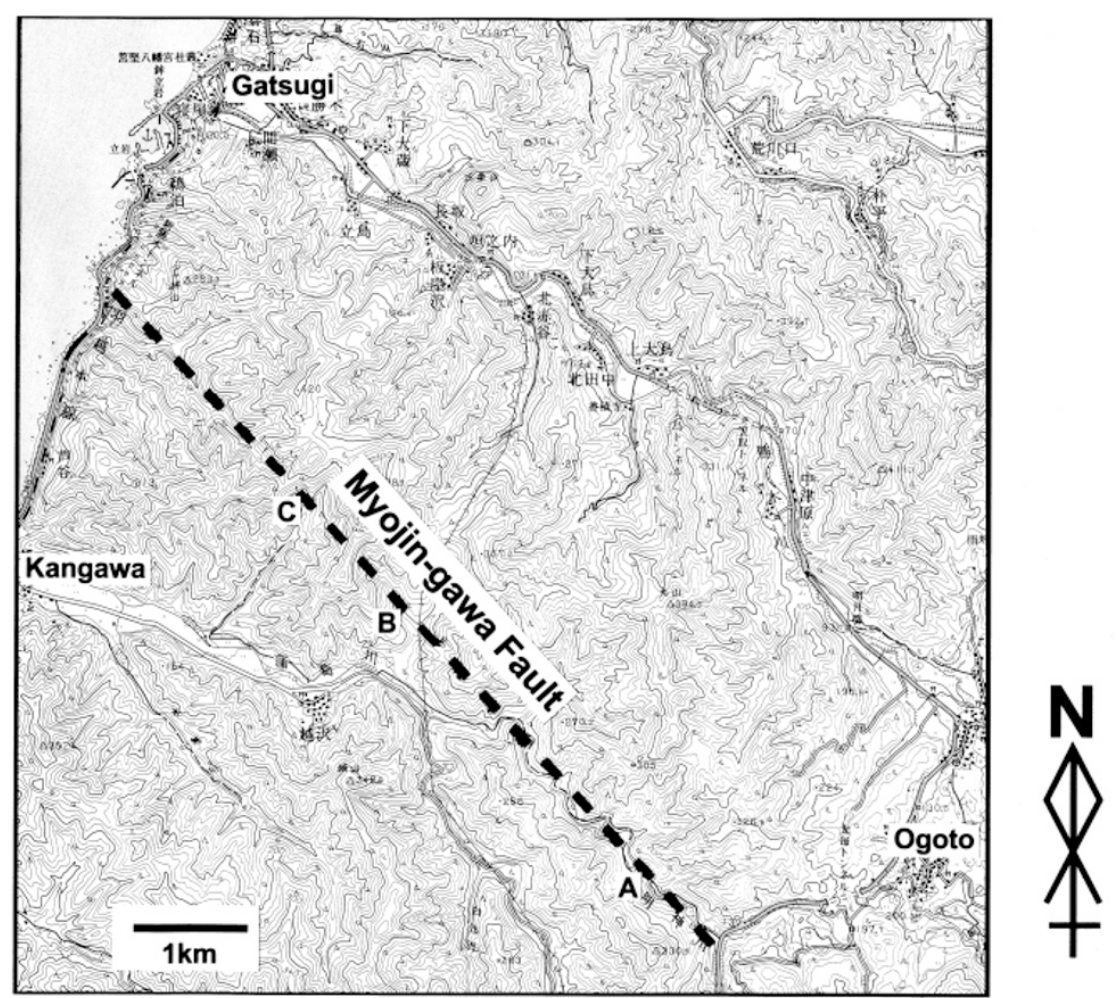

(b)

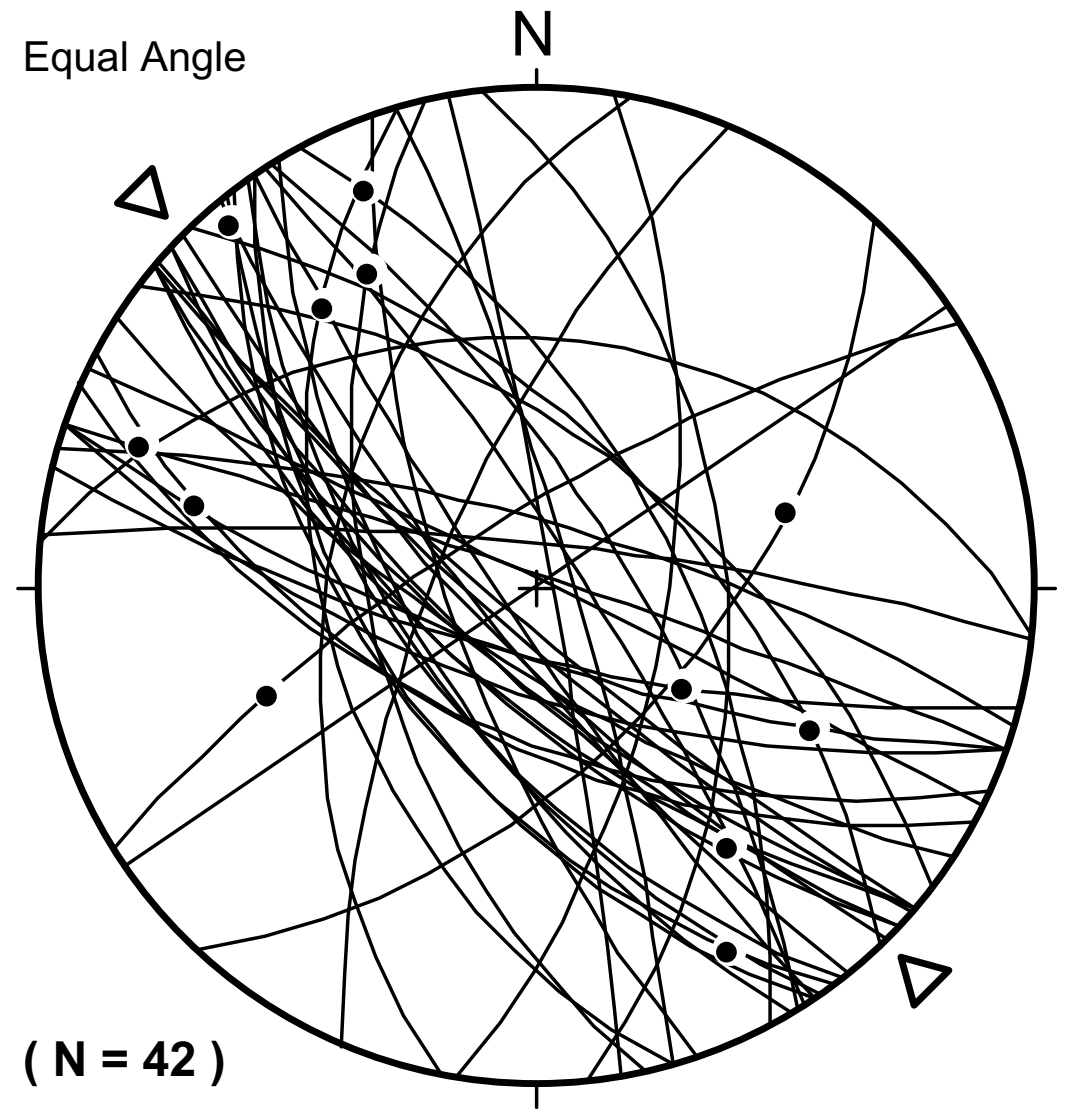

Fig. 7. (a) Map showing the trace of the Myojin-gawa Fault. The fault zone crops out at the localities A, B and C. (b) Lower hemisphere, equal-angle projection showing fault planes in the zone. Great circles exhibit the directions of fault planes. Solid circles on great circles show the directions of striations observed on fault planes, indicating slip directions. Triangles indicate the general trend of the fault zone. 
(a)

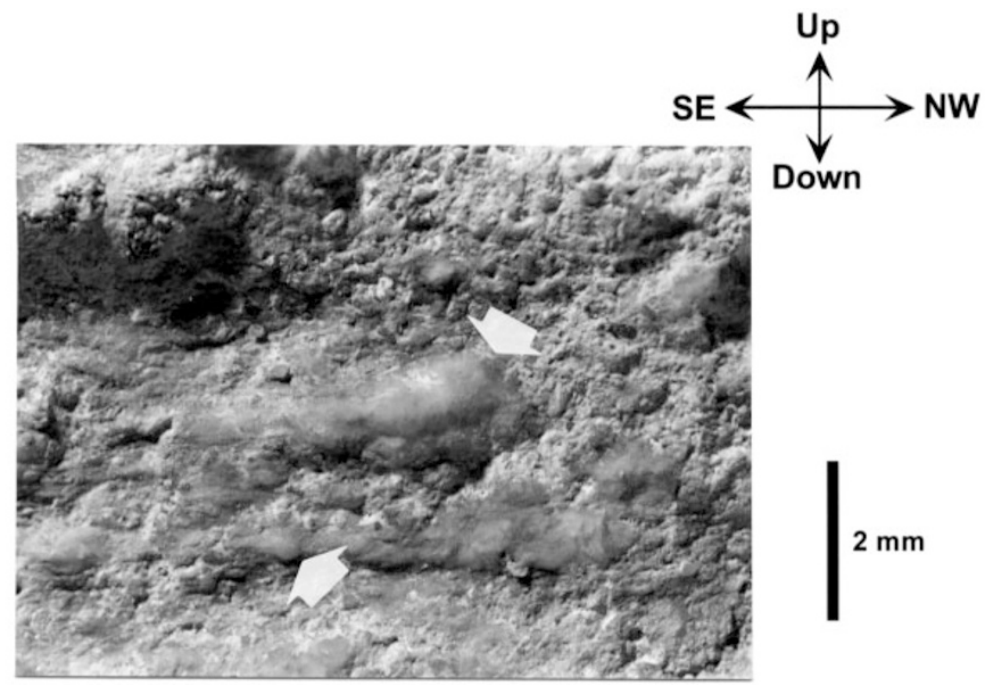

(b)

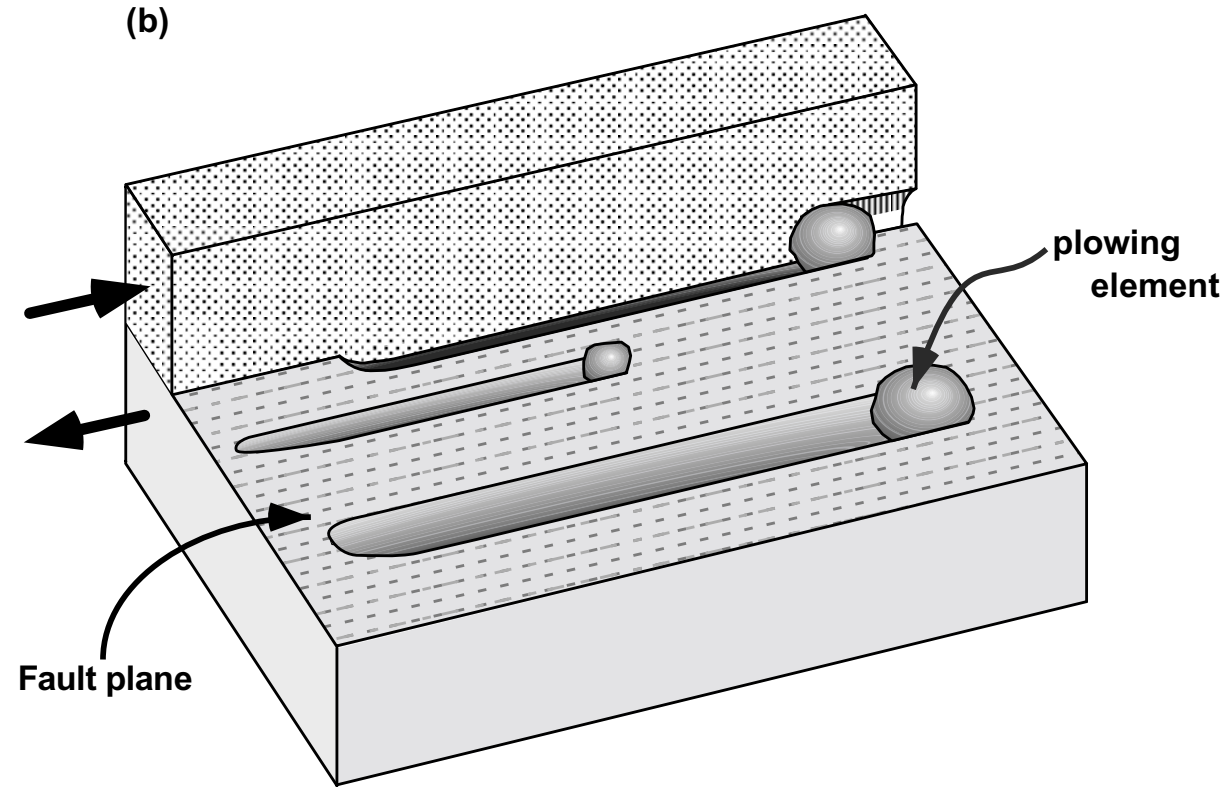

Fig. 8. Asymmetric structures indicating a dextral sense of movement on a shear plane in the Myojin-gawa fault zone. (a) Close-up photograph of striations due to rotating clasts on a shear plane. The clasts have made ridges on their left side as their traces. (b) Schematic picture showing asymmetric ridges and grooves produced by rotating clasts on a shear plane with a dextral sense of movement.

Acknowledgments. We would like to thank Prof. Masayuki Torii (Okayama University of Science), Dr. Masato Tamai (IHS, Kyoto University) and Mr. Koichiro Ito for their helpful advices on paleomagnetism. Thanks are due to Prof. Toshihiko Shimamoto for his useful suggestions on fault rocks. We wish to express our sincere gratitude to the school board of the Asahi Village, Messrs. Yasuo Takahashi and Matsuo Otaki for their kind helps during our field work. Constructive advices by Prof. Yo-ichiro Otofuji and Dr. Hirokuni Oda improved the manuscript. This work was supported by the Grant-in-Aid for Scientific Research $(01790345,08640568)$ from the Ministry of Education, Science and Culture.

\section{References}

Agency of Natural Resources and Energy, Research Report of the Uetsu Region (I), 164 pp., 1982.

Blow, W. H., Late Middle Eocene to Recent planktonic foraminiferal biostratigraphy, in Proceedings of the First International Conference on Planktonic Microfossils (Geneva, 1967), edited by P. Bronnimann and H. H. Renz, pp. 199-422, Leiden, no. 1, 1969.

Fisher, R., Dispersion on a sphere, Proc. Roy. Soc. London, Ser. A, 217,
295-305, 1953.

Ganzawa, Y., Fission track ages of volcanic rocks from Cretaceous to Tertiary in the inner belt of Northeast Japan-Okushiri Island, Oga Peninsula and Asahi Mountains-, J. Geol. Soc. Japan, 93, 387-401, 1987.

Ghosh, S. K. and H. Ramberg, Reorientation of inclusions by combination of pure shear and simple shear, Tectonophys., 34, 1-70, 1976.

Hataya, R. and K. Otsuki, Geology of the Oguni-machi area, Yamagata Prefecture: An example of Early Miocene half-grabens in Northeast Honshu Arc, J. Geol. Soc. Japan, 97, 835-848, 1991.

Hirooka, K., H. Sakai, T. Takahashi, H. Kinoto, and A. Takeuchi, Tertiary tectonic movement of Central Japan inferred from paleomagnetic studies, J. Geomag. Geoelectr., 38, 311-324, 1986.

Hoshi, H. and T. Matsubara, Early Miocene paleomagnetic results from the Ninohe area, NE Japan: Implications for arc rotation and intra-arc differential rotations, Earth Planets Space, 50, 23-33, 1998.

Kirschvink, J. L., The least-squares line and plane and the analysis of palaeomagnetic data, Geophys. J. Roy. Astr. Soc., 62, 699-718, 1980.

Oda, H., M. Torii, and A. Hayashida, Paleomagnetic Study and FissionTrack Dating in Yanagawa and Takadate Area, Northeast Japan, Rock Mag. Paleogeophys., 16, 51-56, 1989.

Otofuji, Y., T. Matsuda, and S. Nohda, Paleomagnetic evidence for the 
Miocene counter-clockwise rotation of Northeast Japan-rifting process of the Japan Arc, Earth Planet. Sci. Lett., 75, 265-277, 1985.

Otofuji, Y., A. Kambara, T. Matsuda, and S. Nohda, Counter-clockwise rotation of Northeast Japan: Paleomagnetic evidence for regional extent and timing of rotation, Earth Planet. Sci. Lett., 121, 503-518, 1994.

Passchier, C. W. and R. A. J. Trouw, Microtectonics, 289 pp., SpringerVerlag, Berlin, 1996.

Petit, J. P., Criteria for the sense of movement on fault surfaces in brittle rocks, J. Struct. Geol., 9, 597-608, 1987.

Ron, H., R. Freund, Z. Garfunkel, and A. Nur, Block rotation by strike-slip faulting: Structural and paleomagnetic evidence, J. Geophys. Res., 89, 6256-6270, 1984.

Sasajima, S., Pre-Neogene paleomagnetism of Japanese islands (and Vicinities), in Paleoreconstruction of the Continents, edited by M. W. McElhinny and D. A. Valencio, pp. 115-128, American Geophysical Union, Washington, D. C., 1981.

Takahama, N., The Neogene System in the Western Slope of the Asahi Massif in the Northern Part of Niigata Prefecture, Japan, Mem. Geol. Soc. Japan, 13, 211-228, 1976.

Takahashi, Y., Geology and structure of the Nihonkoku Mylonite Zone on the borders of Niigata and Yamagata Prefectures, northeast Japan, J. Geol. Soc. Japan, 104, 122-136, 1998.
Ueda, Y., N. Jinbo, and R. Tamiya, K-Ar dating of a lowermost Neogene welded tuff in Yamagata Prefecture, J. Mineral. Petrol. Econom. Geol., 68, 91, 1973.

Yamaji, A., Geology of Atsumi area and Early Miocene rifting in the Uetsu district, northeast Japan, Mem. Geol. Soc. Japan, 32, 305-320, 1989.

Yamaji, A., An Introduction to Tectonophysics, 304 pp., Asakura Publishing Co., Tokyo, 2000.

Yamaji, A., H. Momose, and M. Torii, Miocene Transtensional Deformations at the Eastern Japan Sea Margin, Earth Planets Space, 52, 81-92, 1999.

Yamazaki, T., Paleomagnetism of Miocene sedimentary rocks around Matsushima Bay, Northeast Japan and its implication for the timing of the rotation of Northeast Japan, J. Geomag. Geoelectr., 41, 533-548, 1989.

Yanagisawa, Y. and T. Yamamoto, Geology of the Tamaniwa District, with geological sheet map at 1:50000, 94 pp., Geol. Surv. Japan, 1998.

Zijderveld, J. D. A., A. C. demagnetization of rocks: Analysis of results, in Methods in Paleomagnetism, edited by D. W. Collinson, K. M. Creer, and S. K. Runcorn, pp. 254-286, Elsevier, Amsterdam, 1967.

K. Mino (e-mail: kmino@mac.com), A. Yamaji, and N. Ishikawa 